\title{
V. I. Lytkin käänsi J. H. Erkkoa komiksi
}

Kirjoitus on laajennettu versio V. I. Lytkinin syntymän 100-vuotismuistoseminaarissa Syktyvkarissa 1996 pidetystä esitelmästä. Se on julkaistu otsikolla Илля Васьлӧн финн кывйысь кывбуръяс комиӧдӧм teoksessa В.И.Лыткин и финно-угорский мир (Kokkonen 1999).

Unkaria ja saksaa osaan hyvin, mutta englantia huonommin. Suomeakin osaan, mutta heiltä en oikein löydä tarvittavaa komiksi käännettäväksi. - - Olen kyllä joskus komintanut yhden runon suomalaisten Kalevalaa, mutta aikaa ei löydy sen komintamiseen kokonaan.

Lainaus on peräisin kominkielisen sanomalehden artikkelista (KM 1995). Näin oli valitellut komilainen tiedemies ja kirjailija Vasili Iljitš Lytkin 1920-luvulla. Ilja Vas (Илля Вась), kuten Lytkinin (kirjailija)nimi kuuluu komilaisessa muodossaan, oli kääntänyt suomesta (venäjän kautta) komiksi osan Kalevalan 41. runosta Väinämöisen kanteleen soitto. Sen hän julkaisi ensin Выль туйöd -nimisessä 4. ja 5. luokille tarkoitetussa oppikirjassa vuonna 1923 ja sen jälkeen runokokoelmassaan Kbıвурjac vuonna 1929. Julkaistiinpa hänen käännöksensä Вейнемейненлӧн кантелеӧн ворсӧм vielä kerran vuonna 2003 - nykyisellä komin ortografialla; Lytkin oli käyttänyt ns. Molodtsovin aakkosia (Jugov 2003: 72-73).

Seuraavaksi V. I. Lytkin tarttui J. H. Erkon runoon, johon hän lienee tutustunut lukiessaan M. Gorkin ja V. Brjusovin toimittamaa vuonna 1917 painettua Suomen kirjallisuuden kokoomateosta (Сборникъ Финляндской литературы). Teoksessa on kaksi Erkon runoa. Niistä toisen, Laulu Wuoksella, Lytkin käänsi - oikeastaan mukaeli - vuonna 1924, ja se julkaistiin Komi mu -lehdessä seuraavana vuonna. Komiksi se oli saanut nimen Töвныı 'tuulispää' ja merkinnän "Erkon mukaan". Runo on julkaistu myös kahdessa Lytkinin antologiassa (1929 ja 1985). Brjusov oli venäjäntänyt runon nimellä Пгосня Вуоксы 'Vuoksen laulu' (SFL 187-188). Erkon runossa - kuten Brjusovin venäjännöksessäkin - Saimaan aallot vyöryvät Vuoksessa uhmakkaasti päin kallioita, jotka eivät voi aaltoja kahlita; ahdistettuna aalto rajustuu ja maalle kiusatulle voitonvirttä laulaa Imatra. Samaa kansallisen nousun symboliikkaa on nähtävillä myös Lytkinin versiossa, mutta Vuoksi ja vesi ovat vaihtuneet hänen kominnoksessaan parma-metsäksi ja sen puiksi. Tuulispää riehuu jylhässä komilaismetsässä, parmassa, ja puita taittuu tuulen ulvoessa. Viimeiset viisi riviä paljastavat runon kansallisen sanoman: 
Erkon säkeet (1881: 116):

Niinp’on kansa Suomenmaan, Herättyään, noustuaan, Mahtavasti, Voimakkaasti

Ilkivaltain muurit murtava.

Lytkinin kominnos (1985: 132; myös 1925: 87 ja 1929: 38):

Тӧв ныр мозыс сувт вай, ёрт! Чеччы, мездмӧм коми морт! Аддзан: увгысь Тӧв ныр шувгёПисьтіс вӧля вылӧ шкувгӧмӧн!
Brjusovin venäjännös (SFL 187-188):

Встань, подобенъ вихрю водъ, Спящій, скованный народъ!

Видишь: волны, Гниввомъ полны, Къ воль вырвались, упорныля!

Lytkinin kominnos vapaasti suomennettuna:

Tuulispään tavoin nouse, toveri!

Herä̈̈, vapautunut komilainen!

Näet: ulvova

tuиlispä̈̈ viиһuи...

[Se] murtautui vapauteen ryskyen!

Alkuperäinen Erkon teksti on pikemminkin toteava kuin yllyttävä. Lytkinin imperatiivin käytölle löytyy vastine Brjusovin venäjännöksestä, ei alkukielisestä runosta. Kuriositeettina voi mainita, että Lytkin kävi Suomessa olleessaan Imatralla viettäessään vuonna 1926 heinä-elokuun vaihdetta Rautjärvellä Eino ja Jalo Kaliman vieraana. Todisteena tästä on Komin kirjallisuusmuseossa valokuva, jossa hänen taustanaan kuohuu Vuoksi. Se sama, jonka pauhut hän oli tulkinnut pari vuotta aiemmin parma-metsän huminaksi.

Miten Lytkin sitten pääsi käsiksi Erkon seminaariaikanaan 1870-luvulla kirjoittamaan isänmaalliseen runoon? Kaksi Erkon runoa sisältyy Brjusovin venäjännöksinä edellä mainittuun antologiaan. Tämän teoksen tiedetään udmurttilaisen runoilijan - silloisen kirjallisuuden opiskelijan - Kuzebai Gerdin hankkineen antikvariaatista 1920-luvulla. Lytkin ja Gerd olivat samaan aikaan vuosina 1922-1925 Moskovassa Itäisten kansojen instituutin opiskelijoina ja asuivat maittensa edustustojen asuntolassa. Lytkinin mukaan heillä oli tapana kokoontua usein yhteen laulamaan ja lukemaan runoutta. Käännettävääkin löytyi puolin ja toisin. Lytkin käänsi udmurttilaista runoutta: juuri Gerdiä ja naislyyrikkoa Ašaltši Okia. Oletettavasti toverukset selailivat toistensa kirjojakin. Jos Lytkinillä ei itsellään ollut Suomen kirjallisuuden antologiaa, saattoi hän Gerdiltä sitä lainata. Erkon isänmaallisten runojen kääntämistä muista lähteistä Lytkin ei kuitenkaan jatkanut.

Seuraavan Erkon runon Lytkin käänsi 1927 opiskellessaan Helsingin yliopistossa vuoden verran. Nyt ja sitten -runon kominnos on julkaistu runokokoelmassa vuonna 1929 ja toisen kerran 1985 antologiassa. Runon kirjoittajaa ei mainita, on vain lähdemaininta "suomen kielestä". Runo tuntui tutulta, ja pieni etsiskely johtikin lähteelle: kyseessä on Erkon runo, jonka käännös ei sisällöltään juurikaan poikkea alkuperäisestä. Runo kuvaa lapsen silmin sitä, kuinka kotona huolehditaan lähimmäisistä, mutta suuressa maailmassa on pärjättävä auttajitta, itsenäisesti. Lytkin saattoi 
olla vuonna 1927 jatko-opiskelijana samoissa tunnelmissa Helsingissä kuin Erkko oli ollut tammikuussa vuonna 1885 Münchenissä, jossa hän kirjoitti runonsa.

Öні да мӧдыссь

Ветлӧдльи, сьӧлӧмшӧр кагиньӧй, Джодж кузя тані.

Он вермы усьны тэ - уськӧдчас

Мамыд тэд паныд.

Усьлан кӧть, тэрыба лэптасны,

Гӧгӧрыд видзысь.

Быцман да йӧз костӧ петан кор,

Оз нин ло сідзи:

Былдён сэн тойьиттӧм вӧзйӧ-

Лэптыныныс некод оз кӧсйьл.

(Lytkin 1985: 132; myös 1929: 133)
Nyt ja sitten

Astele, armas pienoinen,

Äitisi ohjaa lastaan;

Et voi langeta, lintunen,

Äitisi ottaa vastaan.

Lankeatko, no, nostetaan,

Luonas on auttajoita.

Mutta, kun joudut maailmaan,

Turhaan huutelet noita:

Siellä ne töykkii toisiaan,

Harva on valmis nostamaan.

(Erkko 1885: 131)

Kolmas Lytkinin kääntämä Erkon runo osui silmiini selaillessani Lytkinin 90-vuotismuistolle vuonna 1985 julkaistua kokoomateosta, josta myös edellä mainitut kaksi Erkon runoa löytyvät. Erkon tunnelmalyriikkaa edustava runo Missä kukka on merkitty antologiassa Lytkinin omaksi runoksi. Tarkistukseni osoitti, että tämä Erkon runo on julkaistu jo Lytkinin runokokoelmassa 1929 - samoin ilman merkintöjä Erkosta. Jää epäselväksi, oliko Lytkin tietoinen runon alkuperästä vai kenties unohtanut merkitä sen. Komissa runoa pidetään Lytkinin runona.

Кӧні дзоридз,

Сэні гожӧм.

Кӧні кодзув,

Сэні енэж.

Кӧні муслун -

Шуд оз кусльь.

(Lytkin 1985: 96; myös 1929: 185)
Missä kukka
Siellä kesä,
Missä tähti,
Siellä taivas,
Missä lempi,
Siellä autuus.

(Erkko 1870: 68)

Käännös on sananmukainen, vain Lytkinin viimeinen säe poikkeaa Erkon runosta; se kuuluisi suomennettuna [siellä] onni ei sammu. Missä kukka on 13. runo Erkon 22 runoa sisältävästä Paimenelta-nimisestä pastoraali-idyllien sikermästä, joka on julkaistu Runoelmissa (vuodet 1868-1870). Miten Lytkin on runon löytänyt ja milloin hän on sen kääntänyt, jää epäselväksi. Selkeäsanaisuutensa ja kokonsa puolesta tämä runo sopi hyvin suomen kielen taidon kohentuessa Lytkinin käännettäväksi.

Suomesta Lytkin siirtyi vuoden 1927 alussa opiskelemaan Unkariin, ja siellä hän kirjoitti pitkän runoelmansa Мунӧны ('Kulkijat', suomeksi antologiassa 
Käenkukuntayöt, s. 96-101). Tämä lokakuun vallankumouksen 10-vuotismuistolle Budapestissa vuonna 1927 kirjoitettu runoelma kävi laatijalleen kohtalokkaaksi. Runoelma ruodittiin perusteellisesti ja sitä syytettiin yhdeksästä puutteesta, mm. puuttuvasta luokkataistelun kuvauksesta. Lytkin kirjoitti runoelmastaan toisenkin version, joka julkaistiin 1959. Мунӧны on komilaisen runouden ehdoton klassikko. Komilaiset tutkijat ovat todenneet runoelman perusteellisen analysoinnin olevan vielä tekemättä.

V. I. Lytkin tutustutti komilaiset lukijat muuhunkin sukukieliseen runouteen. Udmurttirunouden ja Erkon runojen lisäksi hän käänsi Sándor Petőfin runoutta. Vaikka hän käänsikin vain 15 sukukielistä runoa, käännöksillä sanotaan olevan suuri rooli komilaisen runouden etsiessä kansallista muotoaan. Aika, jolloin Lytkin oli aspiranttina Suomessa ja Unkarissa (1926-1928), oli voimakasta kansallisen nousun aikaa niin Komissa kuin muillakin suomalais-ugrilaisten kansojen alueilla. Kun Lytkin oli löytänyt kansallistuntoa kohottavaa käännettävää Erkolta, voisi odottaa, että siihen teemaan hän olisi tarttunut myös Petőfiä kääntäessään. Mutta ei: Lytkin käänsi Petőfin rakkauslyriikkaa! Vallankumoksellinen Petőfi ei kääntynyt komiksi Lytkinin oleskellessa Unkarissa 1927 eikä 1950-luvullakaan, jolloin Lytkin tiedemiehenä teki Petőfikäännöksiään.

On kuitenkin syytä mainita, että runoilijana Lytkin oli erityisen tuottelias Suomessa ollessaan. Hänen 1929 julkaistun runokirjansa paristasadasta runosta lähes 30 on päivätty vuodelle 1926, jolloin 16. helmikuuta hän oli saapunut Helsinkiin. (Pari joulun seudun viikkoa Lytkin vietti Virossa.) Suomessa Lytkinin voi laskea kirjoittaneen 10 kuukauden aikana runon lähes joka viikko. Vuosi 1927 Unkarissa tuotti kymmenkunta runoa.

Pian Lytkinin - aikansa sukukansastipendiaatin - palattua kotiinsa alkoivat Stalinin vainot. Venäjän politiikka teki entisistä opiskelutovereista, Lytkinistä ja Gerdistä, kohtalotovereita ns. SOFIN-asiassa. Heidän uskottiin kuuluvan ryhmään, joka valmisteli suomalais-ugrilaisten alueiden liittämistä Suomeen. Nationalisteina, kulakkien myötäilijöinä ja porvarien kätyreinä heidät - kuten monet muutkin älymystöön kuuluvat - tuomittiin vuonna 1933. Gerd kuoli hämärissä olosuhteissa vankileirillä vuonna 1937. Lytkin lähetettiin kärsimään viiden vuoden tuomiotaan Habarovskiin, josta vapauduttuaan hän jatkoi tieteellistä ja kaunokirjallista uraansa Moskovassa. Hänet rehabilitoitiin 1956, ja kotimaahansa Komiin hän pääsi vuonna 1957. Pitkän päivätyön Lytkin ehti tehdä vielä Komissakin tieteen ja opetuksen parissa. Hän toimi mm. Syktyvkarin yliopiston vuonna 1972 perustetun komin laitoksen ensimmäisenä johtajana. Lytkin kuoli 85-vuotiaana vuonna 1981 kunnioitettuna tiedemiehenä ja tuotteliaana kirjailijana. Monet hänen runoistaan elävät lähes kansanlauluina Komissa - aivan kuten J. H. Erkonkin runot Suomessa. 


\section{Lähteet}

Erkko[, J. H.] 1870: Runoelmia. Helsinki: Suomalaisen Kirjallisuuden Seura.

Erkko, J. H. 1881: Valikoima Runoelmia. Helsinki: K. E. Holm.

Erkko, J. H. 1885: Uusia Runoelmia. Porvoo: Werner Söderström.

Jugov 2003 = Югов, Степан: «Калевала» да коми литература. - Войвыв кодзув 9/2003: $70-74$.

КМ 1995 = Тӧдліс уна кыв. - Коми му 31.10.1995.

Kokkonen 1999 = Кокконен, Паула: Илля Васьлӧн финн кывйысь кывбуръяс комиӧдӧм. - В.И.Льткин и финно-угорский мир. (Сборник статей.) Материаль международной научной конференции, посвященной 100-летию со дня рождения выдающегося коми поэта, философа и ученого В.И.Лыткина (Сыктылкар, 6-9 февраля 1996). Сыктывкар: Министерство по делом национальностей Республики Коми, Коми научный центр УрО Российской академии наук. 145-149.

Käenkukuntayöt. Komien lyriikkaa. Toimittanut ja suomentanut Raija Bartens. Suomalaisen Kirjallisuuden Seuran toimituksia 414. Pieksämäki: Suomalaisen Kirjallisuuden Seura 1984.

Lytkin[, V. I.] 1925 = Литературный отдел. - Комі Мy- Зырянский Край. Экономический и краеведческий журнал 3-4 (13-14) Март-Апрель 1925 года. 81-89.

Lytkin[, V. I.] 1929 = Иљља Вая: Кывбурјас. Стікотвореннӧја. Сыктывdінкар: Комі ніга лезанін.

Lytkin 1985 = Лыткин, В. И.: Дзордзав жё, Коми му. Кывбуръяс, поэмаяс, мойдъяс, висьтъяс. Сыктывкар: Коми книжнӧй издательство.

$\mathrm{SFL}=$ Сборникъ Финляндской литературы. Подъ редакціей В.Брюсова, М.Горькаго. Петроградъ: Издательство „Парусъ“ 1917.

Paula Kokkonen <paula.kokkonen@helsinki.fi>

Volsintie 139

02400 Kirkkonummi 